\title{
Korean Red Ginseng Extract Activates Non-NMDA Glutamate and GABA $A$ Receptors on the Substantia Gelatinosa Neurons of the Trigeminal Subnucleus Caudalis in Mice
}

\author{
Hua Yin, Seon Ah Park, Soo Joung Park, and Seong Kyu Han* \\ Department of Oral Physiology, School of Dentistry and Institute of Oral Bioscience, Chonbuk National University, \\ Jeonju 561-756, Korea
}

\begin{abstract}
Korean red ginseng (KRG) is a valuable and important traditional medicine in East Asian countries and is currently used extensively for botanical products in the world. KRG has both stimulatory and inhibitory effects on the central nervous system (CNS) suggesting its complicated action mechanisms. The substantia gelatinosa (SG) neurons of the trigeminal subnucleus caudalis (Vc) are involved in orofacial nociceptive processing. Some studies reported that KRG has antinociceptive effects, but there are few reports of the functional studies of KRG on the SG neurons of the Vc. In this study, a whole cell patch clamp study was performed to examine the action mechanism of a KRG extract on the SG neurons of the Vc from juvenile mice. KRG induced short-lived and repeatable inward currents on all the SG neurons tested in the high chloride pipette solution. The KRG-induced inward currents were concentration dependent and were maintained in the presence of tetrodotoxin, a voltage gated $\mathrm{Na}^{+}$channel blocker. The KRG-induced inward currents were suppressed by 6-cyano-7-nitroquinoxaline-2,3-dione, a non-N-methyl-D-aspartate (NMDA) glutamate receptor antagonist and/or picrotoxin, a gamma-aminobutyric acid $(\mathrm{GABA})_{\mathrm{A}}$ receptor antagonist. However, the inward currents were not suppressed by d,1-2-amino-5-phosphonopentanoic acid, an NMDA receptor antagonist. These results show that $\mathrm{KRG}$ has excitatory effects on the $\mathrm{SG}$ neurons of the Vc via the activation of non-NMDA glutamate receptor as well as an inhibitory effect by activation of the $\mathrm{GABA}_{\mathrm{A}}$ receptor, indicating the KRG has both stimulatory and inhibitory effects on the CNS. In addition, KRG may be a potential target for modulating orofacial pain processing.
\end{abstract}

Keywords: Panax ginseng, Korean red ginseng, Substantia gelatinosa neuron, Patch-clamp techniques

\section{INTRODUCTION}

Ginseng root (Panax ginseng Meyer) is a valuable and important traditional medicine in East Asian countries and is currently one of the most popular alternative medicines in the world $[1,2]$. Korean red ginseng $(\mathrm{KRG})$ is ginseng that has been cultivated and aged for 4 to 6 years or more, and goes through an extensive cleaning, steaming and drying process [3]. KRG has been shown to have several pharmacological functions, such as antioxidant [4], memory enhancing activities [5], antihypertensive [6], antitumor [7], antistress [8], antidiabetic [9], potentiation of erectile response [10] and aphrodisiac [11].

The substantia gelatinosa (SG), which is the lamina II layer of the trigeminal subnucleus caudalis (Vc), is a critical site for orofacial nociceptive processing because it receives synaptic inputs from the primary myelinated $\mathrm{A} \delta$ and unmyelinated $\mathrm{C}$ fibers [12]. The SG neurons cc This is an Open Access article distributed under the terms of the Cre-
ative Commons Attribution Non-Commercial License (http://creativecom-
mons.org/licenses/by-nc/3.0/) which permits unrestricted non-commercial
use, distribution, and reproduction in any medium, provided the original
work is properly cited.
Received 11 Jan. 2011, Revised 19 May 2011, Accepted 19 May 2011

*Corresponding author

E-mail: skhan@jbnu.ac.kr

Tel: +82-63-270-4030, Fax: +82-63-270-4028 
function as excitatory and inhibitory interneurons, and regulate the output of the projection neurons in lamina I and IV, which transmits noxious information to a higher center [13-17]. Ginseng extract produces analgesia [18] and inhibits pain signaling through neuropeptides, such as bradykinin, substance $\mathrm{P}$ and calcitonin gene related peptide [19]. Recently, Lee et al. [20] also reported that the butanolic fraction of the Panax ginseng rhizome has potential analgesic activity in mice. However, it is unclear if the KRG extract affects directly the SG neuronal activities of the $\mathrm{Vc}$, which is involved in orofacial pain transmission in mice. The present study shows that KRG extract activates the non- N-methyl-D-aspartate (NMDA) glutamate- and gamma-aminobutyric acid $(\mathrm{GABA})_{\mathrm{A}}$ receptors directly.

\section{MATERIALS AND METHODS}

\section{Brain slice preparation}

All experiments were approved by the Experimental Animal Care and Ethics Committee of Chonbuk National University. The mice (Damul Science, Suwon, Korea) were housed under $12 \mathrm{~h}$ light: $12 \mathrm{~h}$ dark cycles (lights on at 07:00 h) with access to food and water ad libitum. Immature (postnatal days 5-15) male and female mice were decapitated between 10:00 and 12:00 $\mathrm{h}$. The brains were removed rapidly and placed in ice-cold bicarbonatebuffered artificial cerebrospinal fluid (ACSF) with the following composition (in $\mathrm{mM}$ ): $126 \mathrm{NaCl}, 2.5 \mathrm{KCl}, 2.4$ $\mathrm{CaCl}_{2}, 1.2 \mathrm{MgCl}_{2}, 11 \mathrm{D}$-glucose, $1.4 \mathrm{NaH}_{2} \mathrm{PO}_{4}$ and 25 $\mathrm{NaHCO}_{3}\left(\mathrm{pH} 7.4\right.$, bubbled with $95 \% \mathrm{O}_{2}$ and $5 \% \mathrm{CO}_{2}$ ). Coronal slices (150 $\mu \mathrm{m}$ thickness) containing the rostral part of the Vc (1-2 mm from obex) were then cut in icecold ACSF using a vibratome (Microm, Walldorf, Germany). The slices were allowed to recover in oxygenated $\mathrm{ACSF}$ for at least $1 \mathrm{~h}$ at room temperature.

\section{Whole cell patch clamp recording}

The brain slices were transferred to the recording chamber, held submerged and superfused continuously with ACSF at a rate of 4 to $5 \mathrm{~mL} / \mathrm{min}$. The slices were viewed using an upright microscope (BX51WI; Olympus, Tokyo, Japan) and Nomarski differential interference contrast optics. The patch pipettes were pulled from the thin-wall borosilicate glass-capillary tubing (PG521514; WPI, Sarasota, FL, USA) on a Flaming puller (P-97; Sutter Instruments Co., Novato, CA, USA). The pipette solution containing (in $\mathrm{mM}$ ) $130 \mathrm{KCl}, 5 \mathrm{NaCl}, 0.4 \mathrm{CaCl}_{2}$, $1 \mathrm{MgCl}_{2}, 10$ HEPES, $4 \mathrm{Mg}$-ATP and 1.1 EGTA (pH 7.3 with $\mathrm{KOH}$ ) was passed through a disposable $0.22 \mu \mathrm{m}$ filter. A glass-capillary electrode was loaded with the pipette solution. The whole cell patch clamp recordings were performed using an Axopatch 200B amplifier (Axon Instruments, Foster City, CA, USA). The tip resistance of the electrode was 4 to $6 \mathrm{M} \Omega$. The membrane currents were sampled online using a Digidata $1322 \mathrm{~A}$ interface (Axon Instruments) connected to an IBM PC. The signals were filtered ( $2 \mathrm{kHz}$, Bessel filter of Axopatch 200B) before digitizing at a rate of $1 \mathrm{kHz}$. The acquisition and subsequent analysis of the acquired data were performed using Clampex9 software (Axon Instruments). The traces were plotted using Origin7 software (MicroCal Software, Northampton, MA, USA). All recordings were performed at room temperature.

\section{Chemicals and statistics}

The KRG extract was kindly provided by Korea Ginseng Corporation (Daejeon, Korea). Six-year-old fresh ginseng roots (Panax ginseng) were harvested in the field in the Republic of Korea in September 2009. KRG was made by steaming fresh ginseng at $90^{\circ} \mathrm{C}$ to $100^{\circ} \mathrm{C}$ for 3 $\mathrm{h}$ and drying at $50^{\circ} \mathrm{C}$ to $80^{\circ} \mathrm{C}$. The $\mathrm{KRG}$ extract contains major ginsenoside $\mathrm{Rb}_{1}(4.06 \%), \mathrm{Rb}_{2}(1.57 \%)$, $\mathrm{Rc}(1.31 \%)$, $\operatorname{Rd}(0.90 \%), \operatorname{Re}(0.70 \%), \operatorname{Rf}(0.50 \%), \operatorname{Rg}_{1}(0.48 \%), \operatorname{Rg}_{2}$ $(0.69 \%), \operatorname{Rg}_{3}(1.94 \%)$ and other minor ginsenosides (Korea Ginseng Corporation). The KRG extract was prepared from a water extract, which was extracted at $87^{\circ} \mathrm{C}$ for $8 \mathrm{~h}$ using six volumes of circulating hot water six times. The pooled extract was concentrated to a water content of $36 \%$. The test compounds were dissolved in an ACSF solution and tested by adding ACSF at known concentrations. 6-Cyano-7-nitroquinoxaline-2,3-dione (CNQX), d,1-2-amino-5-phosphonopentanoic acid (AP5) and the chemicals for ACSF were purchased from Sigma (St. Louis, MO, USA). Tetrodotoxin citrate (TTX) was obtained from Tocris Bioscience (Bristol, UK). All values are expressed as the mean \pm SEM. A paired $t$-test or one sample $t$-test was used to assess the difference the responses. A $p$-value $<0.05$ was considered significant.

\section{RESULTS AND DISCUSSION}

\section{Effects of KRG extract on the SG neuron}

The SG (lamina II) area of the Vc was clearly visible as a translucent band, just medial to the spinal trigeminal tract and traveled along the lateral edge of the slice. The whole-cell patch clamp recordings were obtained from 20 SG neurons in whole cell voltage clamp mode.

A bath application of $3 \mathrm{mg} / \mathrm{mL} \mathrm{KRG}$ caused inward currents in all SG neurons tested $(n=20)$. To determine if 

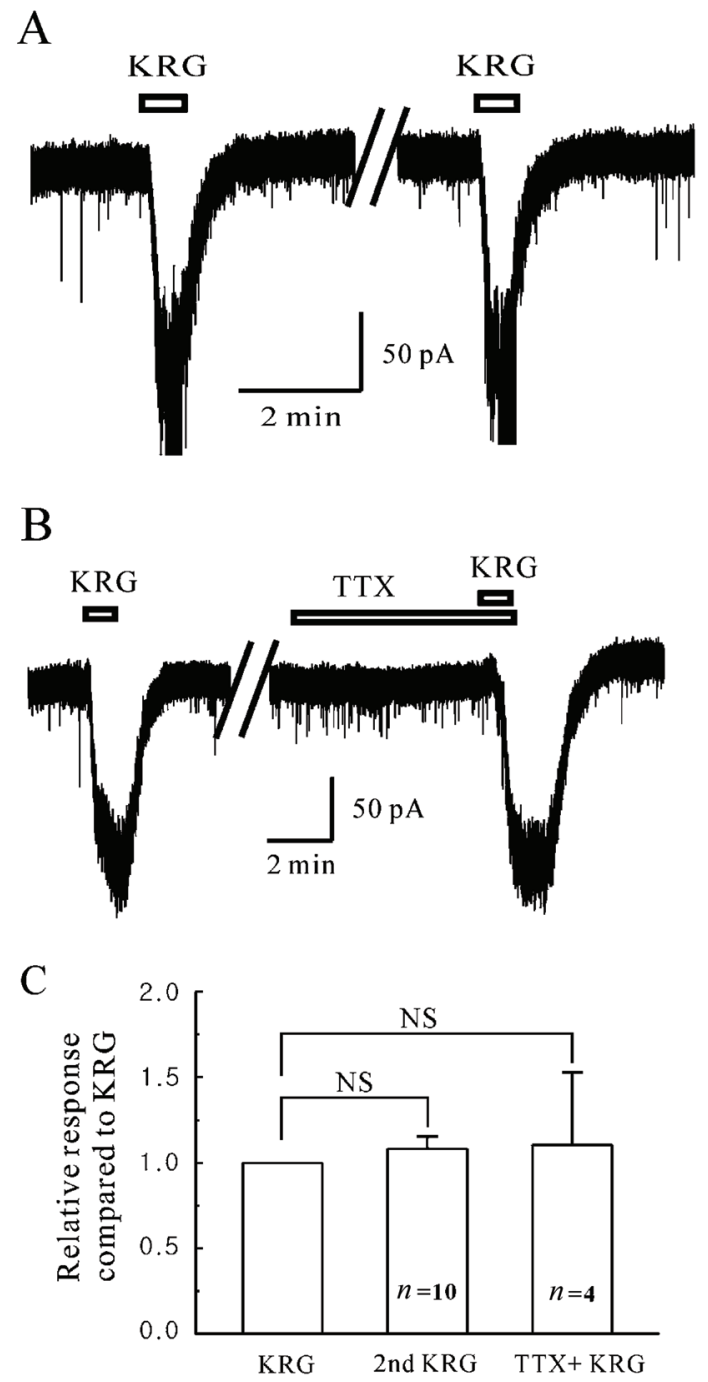

Fig. 1. Responses by Korean red ginseng (KRG) on the substantia gelatinosa neurons of the trigeminal subnucleus caudalis. (A) Representative trace showing the repeatable inward current induced by KRG (3 mg/mL). (B) Representative trace showing inward current induced by KRG application in the presence of tetrodotoxin citrate (TTX) $(0.5 \mu \mathrm{M})$, a voltage gated $\mathrm{Na}^{+}$channel blocker. (C) Relative response of successive application of KRG $(3 \mathrm{mg} / \mathrm{mL}, n=10)$ and in the presence of TTX ( $n=4)$. NS, not significant.

the SG neurons are desensitized by the repeated application of KRG, $3 \mathrm{mg} / \mathrm{mL} \mathrm{KRG}$ was applied successively (Fig. 1A). In the high chloride pipette solution, the SG neurons showed short-lived and reproducible inward currents by successive KRG applications. The response $(-78.4 \pm 10.46 \mathrm{pA}, n=10)$ by the $2 \mathrm{nd}$ application of $\mathrm{KRG}$ was not significantly different from the first response $(-76.2 \pm 12.4 \mathrm{pA}, n=10$, paired $t$-test, $p>0.05$ ) (Fig. 1C). This suggests that no desensitization occurred by the repeated application of KRG on the SG neurons of the Vc.

To determine if KRG acts directly on the SG neurons,
A

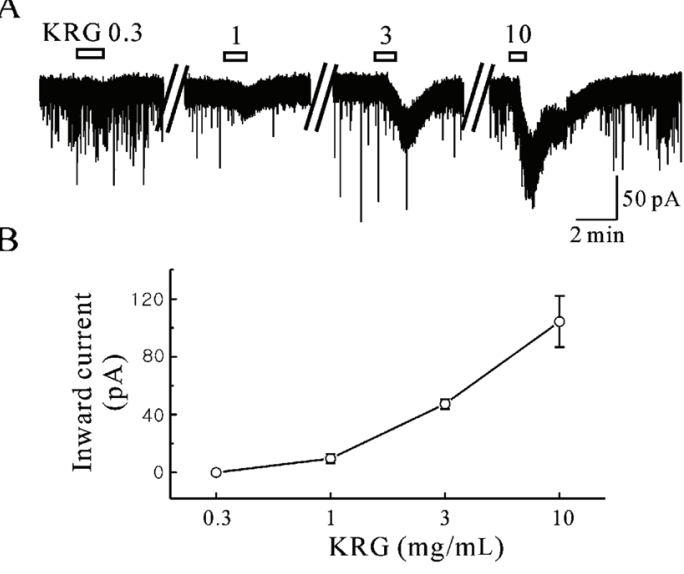

Fig. 2. Concentration-response relationship of Korean red ginseng (KRG) on substantia gelatinosa (SG) neurons. (A) Representative trace from a SG neuron showing a concentration dependent inward current after the application of $0.3,1,3$, and $10 \mathrm{mg} / \mathrm{mL}$ KRG. (B) Concentration response curve showing up grading responses at various KRG concentrations. Each point represents the mean \pm SEM.

the effects of KRG were examined in the presence of tetrodotoxin (TTX, $0.5 \mu \mathrm{M}$ ), a voltage-gated $\mathrm{Na}^{+}$channel blocker that blocks action potential-dependent transmission. The KRG-induced inward currents were maintained in the presence of TTX (Fig. 1B, $n=4$ ). Fig. 1C shows the inward current induced by KRG $(-79.3 \pm 13.3 \mathrm{pA}, n=4)$ in the presence of TTX compared to KRG alone. Fig. 2A shows a representative trace of the concentration dependency by KRG application. The KRG-induced inward currents increased gradually in proportion to the concentration. Fig. 2B shows the mean inward currents by KRG at each concentration $(n=5)$. A concentration-response relationship existed in the $\mathrm{SG}$ neurons that responded to KRG $(0.3 \mathrm{mg} / \mathrm{mL}, 0$ pA; $1 \mathrm{mg} / \mathrm{mL},-10.08 \pm 3.23 \mathrm{pA} ; 3$ $\mathrm{mg} / \mathrm{mL},-41.81 \pm 7.56 \mathrm{pA} ; 10 \mathrm{mg} / \mathrm{mL},-113.6 \pm 17.1 \mathrm{pA}$; $p<0.01, \chi^{2}$ test). This suggests that KRG acts on the postsynaptic SG neurons rather than action potential mediated presynaptic events.

\section{KRG acts on GABA $A_{A}$ and non-NMDA glutamate}

Several studies have shown that ginsenosides, which are main components of ginseng, act on the glutamate receptors or $\mathrm{GABA}_{\mathrm{A}}$ receptors in various regions [21-23]. To determine if the KRG-mediated inward currents are mediated by NMDA receptors on the SG neurons of the Vc in mice, KRG was applied in the presence of AP5, an NMDA glutamate receptor antagonist. As shown in Fig. 3A, AP5 did not affect the KRG-induced inward currents. The relative inward current by KRG in the presence of AP5 was $0.96 \pm 0.015(n=5)$, which is similar to 
A



$\mathrm{C}$

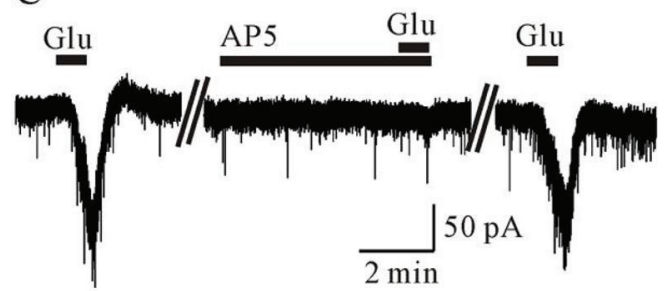

B



$\mathrm{D}$

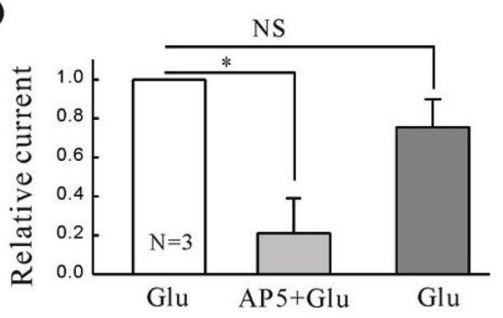

Fig. 3. Korean red ginseng (KRG)-induced inward currents are not mediated by N-methyl-D-aspartate (NMDA) glutamate receptor activation. (A) Representative trace showing inward current induced by KRG application (3 mg/mL) and KRG in the presence of d,l-2-amino-5-phosphonopentanoic acid (AP5), an NMDA receptor antagonist. (B) Relative response of KRG in the presence of AP5 compared to KRG alone ( $n=5)$. (C) Representative trace showing inward current induced by glutamate (Glu, $100 \mu \mathrm{M})$ and glutamate in the presence of AP5. (D) Relative response of glutamate in the presence of AP5 $(20 \mu \mathrm{M})$ compared to glutamate alone $(n=3)$. NS, not significant. ${ }^{*} p<0.05$.

that of KRG alone (One sample $t$-test, $p>0.05$ ), suggesting KRG does not target the NMDA receptors on the SG neurons of Vc (Fig. 3B). To confirm the SG neurons of the $\mathrm{Vc}$ express functional NMDA receptors, we applied glutamate and checked if the glutamate-induced currents are suppressed by AP5. Glutamate $(100 \mu \mathrm{M})$ induced inward currents and the glutamate-induced currents were suppressed by AP5 (Fig. 3C). Fig. 3D shows the relative inward current by glutamate in the presence of $\operatorname{AP} 5(n=3)$.

To determine if the KRG-mediated inward currents are mediated by non-NMDA glutamate receptors on the SG neurons of the Vc, KRG was applied in the presence of 6-cyano-7-nitroquinoxaline-2,3-dione (CNQX), a non-NMDA glutamate receptor antagonist. As shown in Fig. 4A, the KRG-induced inward currents were blocked partially by CNQX $(10 \mu \mathrm{M})$. The relative inward current induced by KRG in the presence of CNQX was $0.44 \pm 0.072(n=5)$ compared to that of $\mathrm{KRG}$ alone $(p<0.05)$ (Fig. 4B), suggesting that KRG acts directly on the non-NMDA glutamate receptor on the SG neurons of the Vc. Furthermore, KRG was also applied in the presence of picrotoxin (PIC), a $\mathrm{GABA}_{\mathrm{A}}$ receptor antagonist, to determine if the KRG-mediated inward currents are mediated by the $\mathrm{GABA}_{\mathrm{A}}$ receptors on the SG neurons of the Vc. As shown in Fig. 4A, the KRG-induced currents were blocked partially by PIC $(50 \mu \mathrm{M}, n=5)$. The relative inward current induced by KRG in the presence of PIC was $0.46 \pm 0.11(n=5)$ compared to that of $\mathrm{KRG}$ alone $(p<0.05)$ (Fig. 4B), suggesting KRG targets the $\mathrm{GABA}_{\mathrm{A}}$ receptors on the $\mathrm{SG}$ neurons of the Vc directly (Fig. 4B). Furthermore, KRG-induced inward currents were blocked completely by CNQX with PIC (Fig. 4A). Fig. $4 \mathrm{~B}$ shows the relative inward current induced by KRG in the presence of CNQX and PIC ( $n=5)$. KRG acts mainly on non-NMDA glutamate receptors and $\mathrm{GABA}_{\mathrm{A}}$ receptors on the SG neurons of the Vc in mice. To confirm the $\mathrm{SG}$ neurons of the Vc express functional $\mathrm{GABA}_{\mathrm{A}}$ receptors, we applied GABA and checked if the GABAinduced currents are suppressed by PIC. PIC $(50 \mu \mathrm{M})$ induced inward currents and the GABA-induced currents were suppressed by PIC (Fig. 4C). Fig. 4D shows the relative inward current by GABA in the presence of PIC $(n=3)$.

A number of ginseng studies have utilized the constituents from three common species: Panax ginseng (Ginseng), Panax quinquefolius (American ginseng), and Panax japonicus (Japanese ginseng). Most pharmacological actions of ginseng are attributed to ginsenosides [24], of which 30 ginsenosides have been isolated [25]. Panax quinquefolius extracts have been reported to reduce the discharge rate of the nucleus tractus solitarius neurons by regulating GABAergic neurotransmission $[21,26]$. In addition, ginsenosides $\mathrm{Rc}$ affected the human recombinant $\mathrm{GABA}_{\mathrm{A}}$ receptor $\left(\alpha_{1} \beta_{1} \gamma_{2 \mathrm{~S}}\right)$ channel activity expressed in Xenopus oocytes. Ginsenosides Rc induced an inward membrane current in certain batches of oocytes 


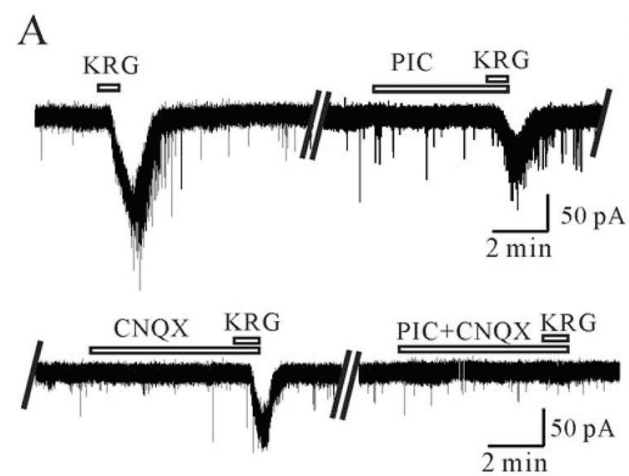

B


D



Fig. 4. Korean red ginseng (KRG)-induced inward currents are mediated by activation of non-N-methyl-D-aspartate (NMDA) glutamate- and/or gamma-aminobutyric acid (GABA) $)_{A}$ receptors. (A) Representative trace showing KRG-induced inward current was blocked by 6-cyano-7-nitroquinoxaline-2,3-dione (CNQX, $10 \mu \mathrm{M})$, a non-NMDA glutamate receptor antagonist and picrotoxin $(\mathrm{PIC}, 50 \mu \mathrm{M})$, a $\mathrm{GABA}_{\mathrm{A}}$ receptor antagonist. (B) Relative response of KRG in the presence of CNQX, PIC, and CNQX with PIC compared to KRG alone ( $n=5)$. (C) Representative trace showing inward current induced by GABA $(100 \mu \mathrm{M})$ and GABA in the presence of PIC. (D) Relative response of GABA in the presence of PIC compared to GABA alone $(n=3) .{ }^{*} p<0.05,{ }^{* *} p<0.01$.

expressing the $\mathrm{GABA}_{\mathrm{A}}$ receptor, which was blocked by picrotoxin. This suggests that ginsenosides regulate the $\mathrm{GABA}_{\mathrm{A}}$ receptor expressed in Xenopus oocytes.

GABA, the chief inhibitory neurotransmitter in the vertebrate central nervous system, has three classes of receptors: $\mathrm{GABA}_{\mathrm{A}}, \mathrm{GABA}_{\mathrm{B}}$ and $\mathrm{GABA}_{\mathrm{C}}$. The activation of ionotropic $\mathrm{GABA}_{\mathrm{A}}$ receptors triggers the opening of a chloride ion-selective channel and tends to stabilize or hyperpolarize the resting membrane potential, which can make it more difficult for excitatory neurotransmitters to depolarize the neuron and generate an action potential [27]. In this study, KRG induced inward currents under a high chloride pipette solution, which were suppressed by picrotoxin, a $\mathrm{GABA}_{\mathrm{A}}$ receptor antagonist, suggesting that KRG has GABA-mimetic inhibitory action through the $\mathrm{GABA}_{\mathrm{A}}$ receptors on SG neurons.

Many studies reported that ginsenosides $\mathrm{Rb}_{1}$ and $\mathrm{Rg}_{3}$ have significant neuroprotective effects against glutamate-induced cortical neuron damage in vitro [28]. Ginseng total saponins and ginsenoside $\mathrm{Rg}_{3}$ inhibited the NMDA-induced increase in the intracellular free $\mathrm{Ca}^{2+}$ concentration $\left(\left[\mathrm{Ca}^{2+}\right] \mathrm{i}\right)$ and less effectively glutamateinduced increase in $\left[\mathrm{Ca}^{2+}\right]_{\mathrm{i}}$ in cultured hippocampal neurons [22]. In addition, ginsenoside $20(\mathrm{~S})-\mathrm{Rh}_{2}$ and $\mathrm{Rg}_{3}$ have an inhibitory effect in cultured hippocampal neurons by selectively targeted the NMDA receptors [23]. However, the ginseng-induced responses of the non-NMDA glutamate receptors have not been studied. In this study, the KRG-induced inward currents were maintained in the presence of AP5, an NMDA glutamate receptor antagonist but suppressed in the presence of CNQX, a non-NMDA glutamate receptor antagonist, suggesting that KRG has an excitatory response via the activation of the non-NMDA glutamate receptor on the SG neurons. To our knowledge, it is the first report of non-NMDA receptor-mediated action of KRG. In addition, the KRG-induced inward currents were blocked completely by the simultaneous application of CNQX and picrotoxin, suggesting the KRG has both excitatory and inhibitory effects on SG neurons though the association of $\mathrm{GABA}_{\mathrm{A}}$ and non-NMDA glutamate receptors.

Ginsenosides, the major active components of ginseng, are a diverse group of steroidal saponins that produce an array of pharmacological responses. Ginsenosides and other constituents of ginseng have a range of effects, and a single ginsenoside can initiate multiple actions [29]. This may explain the difference between the present study and others, in that KRG has excitatory effects on SG neurons of $\mathrm{Vc}$ via the activation of non-NMDA glutamate receptors. 
In conclusion, KRG has both excitatory and inhibitory effects on SG neurons and affects the SG neuronal activities of the $\mathrm{Vc}$ by activating the $\mathrm{GABA}_{\mathrm{A}}$ and non-NMDA glutamate receptors. These results suggest that KRG may be a potential target for orofacial pain modulation at the brain stem level. Further studies will be needed to isolate and identify the compounds related to the KRG-mediated actions.

\section{ACKNOWLEDGEMENTS}

The authors wish to thank Korea Ginseng Corporation for kindly providing the KRG extract. This study was supported by the Basic Science Research Program through the National Research Foundation of Korea funded by the Ministry of Education, Science and Technology (2009-0067150).

\section{REFERENCES}

1. Attele AS, Wu JA, Yuan CS. Ginseng pharmacology: multiple constituents and multiple actions. Biochem Pharmacol 1999;58:1685-1693.

2. Tachikawa E, Kudo K, Harada K, Kashimoto T, Miyate Y, Kakizaki A, Takahashi E. Effects of ginseng saponins on responses induced by various receptor stimuli. Eur J Pharmacol 1999;369:23-32.

3. Yun TK. Brief introduction of Panax ginseng C.A. Meyer. J Korean Med Sci 2001;16 Suppl:S3-S5.

4. Han BH, Park MH, Han YN. Studies on the anti-oxidant components of Korean ginseng. In: Korea Ginseng Research Institute. Proceedings of Second International Ginseng Symposium; Seoul, Korea, 1978;13-17.

5. Jin SH, Park JK, Nam KY, Park SN, Jung NP. Korean red ginseng saponins with low ratios of protopanaxadiol and protopanaxatriol saponin improve scopolamine-induced learning disability and spatial working memory in mice. J Ethnopharmacol 1999;66:123-129.

6. Jeon BH, Kim CS, Kim HS, Park JB, Nam KY, Chang SJ. Effect of Korean red ginseng on blood pressure and nitric oxide production. Acta Pharmacol Sin 2000;21:10951100.

7. Surh YJ, Ferguson LR. Dietary and medicinal antimutagens and anticarcinogens: molecular mechanisms and chemopreventive potential-highlights of a symposium. Mutat Res 2003;523-524:1-8.

8. Kaneko H, Nakanishi K. Proof of the mysterious efficacy of ginseng: basic and clinical trials. Clinical effects of medical ginseng, Korean red ginseng: specifically, its anti-stress action for prevention of disease. J Pharmacol
Sci 2004;95:158-162.

9. Vuksan V, Sung MK, Sievenpiper JL, Stavro PM, Jenkins AL, Di Buono M, Lee KS, Leiter LA, Nam KY, Arnason JT et al. Korean red ginseng (Panax ginseng) improves glucose and insulin regulation in well-controlled, type 2 diabetes: results of a randomized, double-blind, placebocontrolled study of efficacy and safety. Nutr Metab Cardiovasc Dis 2008;18:46-56.

10. Choi HK, Seong DH, Rha KH. Clinical efficacy of Korean red ginseng for erectile dysfunction. Int J Impot Res 1995;7:181-186.

11. De Andrade E, de Mesquita AA, Claro Jde A, de Andrade PM, Ortiz V, Paranhos M, Srougi M. Study of the efficacy of Korean red ginseng in the treatment of erectile dysfunction. Asian J Androl 2007;9:241-244.

12. Sessle BJ. Mechanisms of trigeminal and occipital pain. Pain Rev 1996;3:91-116.

13. Gobel S, Falls WM, Bennett GJ, Abdelmoumene M, Hayashi H, Humphrey E. An EM analysis of the synaptic connections of horseradish peroxidase-filled stalked cells and islet cells in the substantia gelatinosa of adult cat spinal cord. J Comp Neurol 1980;194:781-807.

14. Kumazawa T, Perl ER. Excitation of marginal and substantia gelatinosa neurons in the primate spinal cord: indications of their place in dorsal horn functional organization. J Comp Neurol 1978;177:417-434.

15. Light AR, Perl ER. Reexamination of the dorsal root projection to the spinal dorsal horn including observations on the differential termination of coarse and fine fibers. $\mathrm{J}$ Comp Neurol 1979;186:117-131.

16. Light AR, Kavookjian AM. Morphology and ultrastructure of physiologically identified substantia gelatinosa (lamina II) neurons with axons that terminate in deeper dorsal horn laminae (III-V). J Comp Neurol 1988;267:172-189.

17. Pan YZ, Pan HL. Primary afferent stimulation differentially potentiates excitatory and inhibitory inputs to spinal lamina II outer and inner neurons. J Neurophysiol 2004;91:2413-2421.

18. Bhargava HN, Ramarao P. The effect of Panax ginseng on the development of tolerance to the pharmacological actions of morphine in the rat. Gen Pharmacol 1991;22:521525.

19. Sampson JH, Phillipson JD, Bowery NG, O'Neill MJ, Houston JG, Lewis JA. Ethnomedicinally selected plants as sources of potential analgesic compounds: indication of in vitro biological activity in receptor binding assays. Phytother Res 2000;14:24-29.

20. Lee JH, Lee JH, Lee YM, Kim PN, Jeong CS. Potential analgesic and anti-inflammatory activities of Panax gin- 
seng head butanolic fraction in animals. Food Chem Toxicol 2008;46:3749-3752.

21. Choi SE, Choi S, Lee JH, Whiting PJ, Lee SM, Nah SY. Effects of ginsenosides on GABA(A) receptor channels expressed in Xenopus oocytes. Arch Pharm Res 2003; 26:28-33.

22. Kim S, Ahn K, Oh TH, Nah SY, Rhim H. Inhibitory effect of ginsenosides on NMDA receptor-mediated signals in rat hippocampal neurons. Biochem Biophys Res Commun 2002;296:247-254.

23. Lee E, Kim S, Chung KC, Choo MK, Kim DH, Nam G, Rhim H. 20(S)-ginsenoside $\mathrm{Rh}_{2}$, a newly identified active ingredient of ginseng, inhibits NMDA receptors in cultured rat hippocampal neurons. Eur J Pharmacol 2006;536:69-77.

24. Huang KC. The pharmacology of Chinese herbs. Boca
Raton: CRC Press, 1999.

25. Gillis CN. Panax ginseng pharmacology: a nitric oxide link? Biochem Pharmacol 1997;54:1-8.

26. Yuan CS, Attele AS, Wu JA, Liu D. Modulation of American ginseng on brainstem GABAergic effects in rats. J Ethnopharmacol 1998;62:215-222.

27. Johnston GA. GABA $A_{A}$ receptor pharmacology. Pharmacol Ther 1996;69:173-198.

28. Kim YC, Kim SR, Markelonis GJ, Oh TH. Ginsenosides $\mathrm{Rb}_{1}$ and $\mathrm{Rg}_{3}$ protect cultured rat cortical cells from glutamate-induced neurodegeneration. J Neurosci Res 1998; 53:426-432.

29. Shi W, Wang Y, Li J, Zhang HQ, Ding L. Investigation of ginsenosides in different parts and ages of Panax ginseng. Food Chem 2007;102:664-668. 